\title{
"Nonmorphological Derivations" and the Four Main English Learner's Dictionaries
}

Geart van der Meer, Department of English, University of Groningen, The Netherlands (vdmeer@let.rug.nl)

\begin{abstract}
This article addresses the problem of "nonmorphological derivations" in English and its consequences for pedagogical lexicography, i.e. learner's dictionaries. The term "nonmorphological derivation" refers to cases such as sun — solar, moon - lunar, cat - feline, and in general to all cases where instead of, or in addition to, native derivational processes (sunny, moony, catty) English frequently uses borrowings especially from Romanic sources (Latin/French) and from Greek. The paper suggests that for such cases learner's dictionaries should give more active guidance and support, in view of the fact that many foreign learners will be from linguistic backgrounds where different, more native morphological processes are more common. An appendix lists the major examples of such derivatives.
\end{abstract}

Keywords: LEARNER'S DICTIONARIES, PEDAGOGICAL LEXICOGRAPHY, DICTIONARY DESIGN, FOREIGN LANGUAGE TEACHING, MORPHOLOGY, MORPHOLOGICAL OPACITY AND TRANSPARENCY, STRUCTURE AND CHARACTER OF THE LEXICON.

Opsomming: "Niemorfologiese afleidings" en die vier vernaamste Engelse aanleerderswoordeboeke. Hierdie artikel bespreek die probleem van "niemorfologiese afleidings" in Engels en die uitwerking daarvan op die pedagogiese leksikografie, d.w.s. aanleerderswoordeboeke. Die term "niemorfologiese afleiding" verwys na gevalle soos sun - solar, moon lunar, cat - feline, en oor die algemeen na alle gevalle waar in plaas van of ter aanvulling van, natuurlike afleidingsprosesse (sunny, moony, catty) Engels dikwels ontlenings gebruik veral aan Romaanse bronne (Latyn/Frans) en aan Grieks. Die artikel doen aan die hand dat aanleerderswoordeboeke in sulke gevalle meer aktiewe leiding en bystand behoort te gee, gesien die feit dat baie van die vreemde aanleerders van linguistiese agtergronde sal wees waar ander, meer inheemse morfologiese prosesse meer algemeen is. 'n Bylae lys die belangrikste voorbeelde van sulke afleidings.

Sleutelwoorde: AANLEERDERSWOORDEBOEKE, PEDAGOGIESE LEKSIKOGRAFIE, WOORDEBOEKONTWERP, VREEMDETAALONDERWYS, MORFOLOGIE, MORFOLOGIESE ONDEURSIGTIGHEID EN DEURSIGTIGHEID, STRUKTUUR EN KARAKTER VAN DIE WOORDEBOEK.

\section{Introduction ${ }^{1}$}

English, as is well-known, unites strands of vocabulary from many sources, due to the checquered political, social, cultural and therefore linguistic history 
of the English-speaking peoples. One of the specific consequences of this history is the remarkably rich, versatile and flexible vocabulary of English, which often gives the user a choice of several words with subtle and useful differences in meaning. One of the disadvantages of this development is the frequently opaque character of the English vocabulary, which not only presents problems to the learner but occasionally to the native speaker as well. ${ }^{2}$

The mixed origins of English have led to a situation where words with obvious semantic links are frequently formally totally unrelated in cases where other languages such as Dutch and German have both a semantic and a formal link by means of morphological derivation and composition. Take for example the adjective to the Dutch noun koning "king", which is koninklijk "royal, regal". This adjective is semantically clearly motivated and comparatively transparent, because it is morphologically (so formally) largely nonopaque, ${ }^{3}$ whereas the English near-equivalents royal and regal are not, though the -al suffix to some extent does at least suggest that the words are adjectives. The fact that English, in addition, also has the transparently derived adjective kingly demonstrates on the one hand the richness of the English vocabulary, and on the other hand the choices with which the speakers of English, and especially the nonnative ones, are confronted. For though the three words are semantically related, they are certainly not synonymous.

The mainly French, Latin and Greek foreign heritage of the English language has made huge zones of its vocabulary (relatively) unmotivated, or one might also say, morphologically "opaque", i.e. morphologically and hence semantically unanalysable. As a further example, the words opaque and transparent themselves might be considered. The "derived" nouns to these adjectives are opacity and transparency respectively, somewhat less than productive formations. The adjectives themselves are totally unmotivated as well, apart maybe from the fact that the -ent of transparent may be intuited as an adjectival ending. Perhaps the "prefix" trans- also adds some modest amount of semantic motivation, or at least some suggestion of morphological complexity.

The Dutch equivalents are doorzichtig and ondoorzichtig respectively, meaning roughly "through-see-able" and "un-through-see-able".4 The derived nouns are doorzichtigheid and ondoorzichtigheid, "through-see-able-ness" and "unthrough-see-able-ness", formed by means of adding the nominalising suffix -heid. German, of which the vocabulary in this respect is often even more systematic and hence morphologically transparent than that of Dutch, offers the example of the four words Jahr, Jahrzehnt, Jahrhundert and Jahrtausend, for which English has year, decade, century and millennium, which concisely sum up the origins of English (from Germanic, Greek, and Latin (twice) respectively). ${ }^{5}$

Though speakers of English may consider such words ponderous, this is certainly not the view of speakers of other languages such as Dutch and German, who find it strange that the adjective to sun is solar, as in solar eclipse, which to them is simply "sun-darkening" or "sun-darkness", cf. Dutch zonsverduistering and German Sonnenfinsternis respectively. ${ }^{6}$ The words sun and solar still have the initial consonant in common, but the situation is more difficult in 
most other cases, for example in filial devotion, where there is phonetically no resemblance between child/son/daughter and filial. Though in such cases learner's dictionaries often offer, by means of keywords in their sense definitions, the direction from adjective to noun (solar > sun), the opposite normally does not hold. In this article, I intend to examine to what extent the users of such dictionaries can, or cannot, find their way to the nonmorphologically derived words. By "nonmorphologically derived", I somewhat loosely mean cases such as (sun $>$ ) solar, $(\operatorname{dog}>)$ canine, etc. and generally similar cases, where - to put it informally - the semantic description of the "derivative" includes, or refers to, the semantic description of the morphologically absent "base", without there being any formal morphological link, as there clearly is in sun > sunny. After examining the four main learner's dictionaries, I will formulate a proposal as to how the prevalent situation can be improved and remedied.

\section{2. "Nonmorphological derivations" and the learner's dictionaries}

The four best-known learner's dictionaries, the "big four" (OALD, CC, CIDE, LDOCE), are intended for both encoding and decoding purposes, though it seems that recently the latter has been gaining ground at the expense of the former (Cowie 1999: 176). In my opinion, however, one of the tasks of such dictionaries is to make learners (more) aware of the major links between vocabulary items. In this section, I intend to examine how the four dictionaries manage, or do not manage, to link "base" and "derivative" in cases such as sun $>$ solar. In other words, how can learners speaking Dutch, German or any other language that far less often than English uses Latin and Greek "derivations", find their way from sun to solar, moon to lunar, etc. without using a bilingual dictionary? To this end I have checked the entries for a number of test cases drawn from a larger collection listed in the appendix. This list of test cases is mainly based on Van der Meer (2000) with some recent additions.

The following conclusions can be drawn. In most cases it is not too difficult to discover to which English "base" word a Latin or Greek "derived" form belongs, since the sense definitions usually mention the "base", e.g. feline (in all four dictionaries) mentions cat. ${ }^{8}$ It is therefore possible to find one's way back to the "base". However, the compilers of these dictionaries seem unaware that many foreign learners speak languages which show semantic links much more clearly by means of their morphology. Such learners naturally tend to expect the same in English. The consequence of this is that they find it impossible to trace adjectives such as solar and lunar when starting from the "bases" sun and moon. Hence any user wishing to form words or word combinations involving moon is left guessing and has to consult a bilingual dictionary.

Occasionally, however, certain links are presented, but this is not due to a real policy but entirely coincidental, and based on synonymy rather than derivational considerations. Thus, at body CIDE uses physical structure as a "guideword", which would allow the attentive learner to find their way to physical. In other cases certain jumps are made possible from the Anglo-Saxon derived 
form to the foreign "derived" adjective, as in the case of eatable, where both OALD and CIDE cross-refer the user to edible. Reversely, CIDE and LDOCE, but not OALD, also allow the user to go from edible to eatable.

CIDE, in a quite unpredictable and unexplainable way, occasionally offers some help: under flower the reference "See also FLORAL" is given. Since CIDE, under father, mother, brother and moon, for example, does not provide such a reference, this is apparently a random, though not quite unique, hit: CIDE does the same under hell (where there is a cross-reference to hellfire; hellhole; infernal) and under night (where there is a rather unexpected reference to nocturnal). ${ }^{9}$

There are also some apparently random cases where a cross-reference is given from the one foreign adjective to the other, as at regal and royal: from regal the OALD gives a reference to royal, and vice versa. Likewise, LDOCE refers royal to regal, though, rather inconsistently, not back again. For all four dictionaries the male, masculine, female, feminine group also involves a certain amount of cross-referencing (in the case of CC in the extra column, as was to be expected). ${ }^{10}$

The emerging picture is clear, however: not one of the four learner's dictionaries is really concerned with helping the user find the way from moon to lunar and similar cases, though there are some random exceptions. The possibly relevant cross-references characteristically involve synonymy instead of derivational relations. Even in OALD, which in its latest edition has introduced the novelty of "word families" that "show all words related to the headword", this usually means only families linked by strictly formal, morphological, relations. The only other family members recognised by OALD are synonyms and antonyms. Moreover, the word family boxes are comparatively rare.

One would have expected that CIDE, the only learner's dictionary left with nesting of derived forms whenever alphabetical order is not disturbed too dramatically, and hence with a certain awareness of important semantic links, would have shown the greatest awareness of the strong links between e.g. moon -lunar, yet this is not the case. The links that do occur are obviously haphazard.

\section{Suggestions for improvement}

Learner's dictionaries, with their focus on encoding and vocabulary building in addition to decoding, should have shown a greater awareness of the need of foreign learners in this particular respect. The character of English, with its large Latin and Greek vocabulary, is such that it often relies on foreign roots and borrowings in comparison with other languages with a different linguistic history. Learners from other European languages with a certain common classical linguistic heritage may still be able to overcome this particular hurdle in English, since not all English "nonmorphological derivatives" will be unfamiliar to them. Yet they too would be better served by a learner's dictionary which does recognise this problem. And learners from non-European backgrounds would, I suspect, need help in this respect even more. 
This particular problem could therefore be solved in one of two possible ways. The first and most natural possibility would be to make liberal use of cross-references from e.g. sun to solar, possibly, though not necessarily, from sun to sunny, and certainly also from sunny to solar and vice versa. To the extent that the definitions and possible examples would not sufficiently discriminate between solar and sunny short usage notes might be inserted explaining when to use which. A second, though much less preferred solution would be to list the most important cases in an appendix to the dictionary. Its disadvantage would be that dictionary users usually do not seem to consult such appendices because they are often unaware of them.

\section{Conclusion}

In the appendix, I have listed the 166 words with "nonmorphological derivatives" I was able to find by introspection and by more direct searches. A number of them will not be directly relevant to learners but in my opinion most of them will. Since I have also included cases such as calf — veal, the notion of "derivative" should not be interpreted too strictly. The number of such cases is, however, small, and the majority of cases listed are examples of "derived" adjectives - sometimes verbs - taken from either Latin (directly or by way of French) or Greek, thus from a foreign source. Frequently, the base is an AngloSaxon word (e.g. blood) or an originally borrowed word (e.g. bishop, itself ultimately from Greek) which has become part of the ordinary "core" vocabulary. The "nonmorphological derivatives" are then occasionally the less adapted forms from the same source (such as episcopal) or forms from a totally different source (e.g. ventral, adjective to belly).

The list clearly reveals the character of the English vocabulary: derived from a number of highly diverse sources and, in addition to and alongside morphological derivation proper for its word formation, frequently using borrowings from another language. The degree of morphological transparency is therefore irregular, depending on whether there is real derivation (e.g. breakable) or not (e.g. fragile). Since breakable clearly connects with break, it is not only morphologically but also semantically dependent on break in a way fragile is not. English, in comparison to Dutch, seems to have a vocabulary with a higher percentage of what can be termed "semantically independent" words, by which I mean words such as fragile which have no morphological links. It also seems that English more often has a separate word for each different meaning. Thus, where most languages would say "pig meat", English has pork, and where many languages would have a derived adjective "feelable", English has palpable and tangible. This has, as I have argued, consequences for learners from languages with a different character. It will be interesting to see how the morphologically derived and "nonmorphologically derived" forms have semantically diverged (or not) and what particular divergence patterns can be observed. 


\section{Appendix}

\section{List of words and their "nonmorphological derivations"}

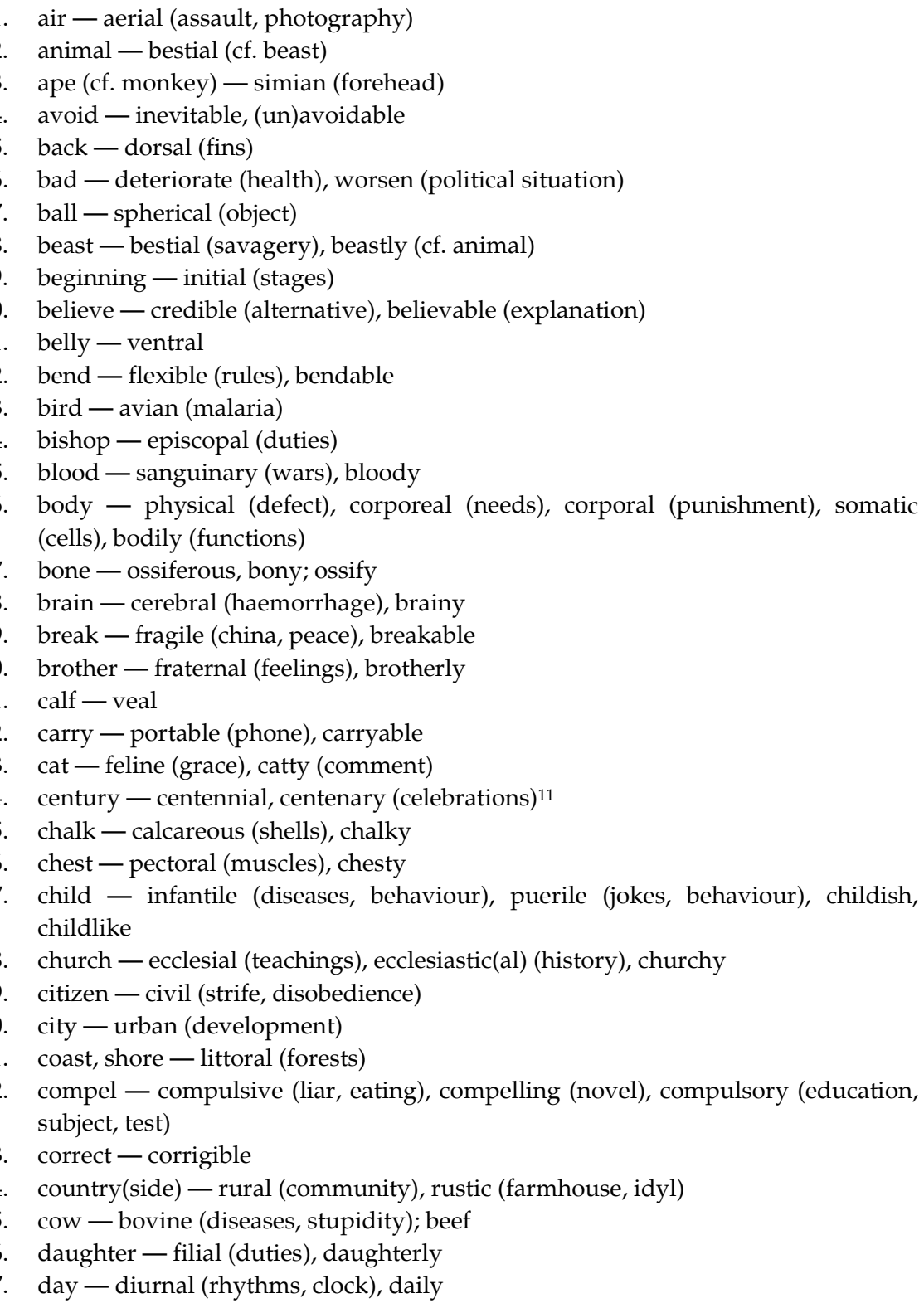


38. death - lethal (weapons, blow), mortal (wound, enemy), deathly, deadly

39. deceive - deceptive (appearances)

40. do - feasible, practicable; doable

41. dog — canine (tooth, behaviour), doggy, doglike

42. donkey, ass — asinine (remark)

43. ear - aural (test)

44. earth - terrestrial (TV channels), earthly, earthy

45. east - oriental (art), easterly, eastern

46. eat - edible (snails, fungi), eatable

47. eighty - octogenarian 12

48. empire - imperial

49. enemy - hostile (attitude), inimical (climate, conditions, influence)

50. eagle - aquiline

51. eye - ocular (defects)

52. fast - accelerate (rate of growth), speed up

53. father - fatherly, paternal (authority); fatherhood, paternity

54. feel - palpable, tangible

55. fever - febrile (activity), feverish

56. flesh - carnal (desires, knowledge), fleshy

57. flower - floral (pattern), florid (style), flowery

58. forget - oblivious; forgetful

59. fox - vulpine; foxy

60. friend - amicable (settlement), friendly

61. god - divine (wisdom, inspiration), godlike, godly

62. good - improve (health), ameliorate (working conditions)

63. hair - hirsute (animals), hairy

64. hear - audible

65. heart - cordial (smile), cardiac (arrest), hearty

66. heat - thermal (energy)

67. heaven - celestial (bodies, beauty), heavenly

68. heavy - gravity, heaviness

69. hell — infernal (heat, machine), hellish

70. horse - equine; hors(e)y

71. ice - glacial; icy

72. iron - ferrous (metals), iron (constitution, determination)

73. island - insular

74. joke - jocular (remarks), jocose, jokey

75. king - regal (splendour), royal (family), kingly (bearing) (cf. queen)

76. language - linguistic, lingual

77. laugh — risible, ridiculous, laughable

78. law - legal, juridical

79. lie - recumbent (figure), lying

80. life - vital (functions, organs), lively

81. light - luminous (paint), illuminate 


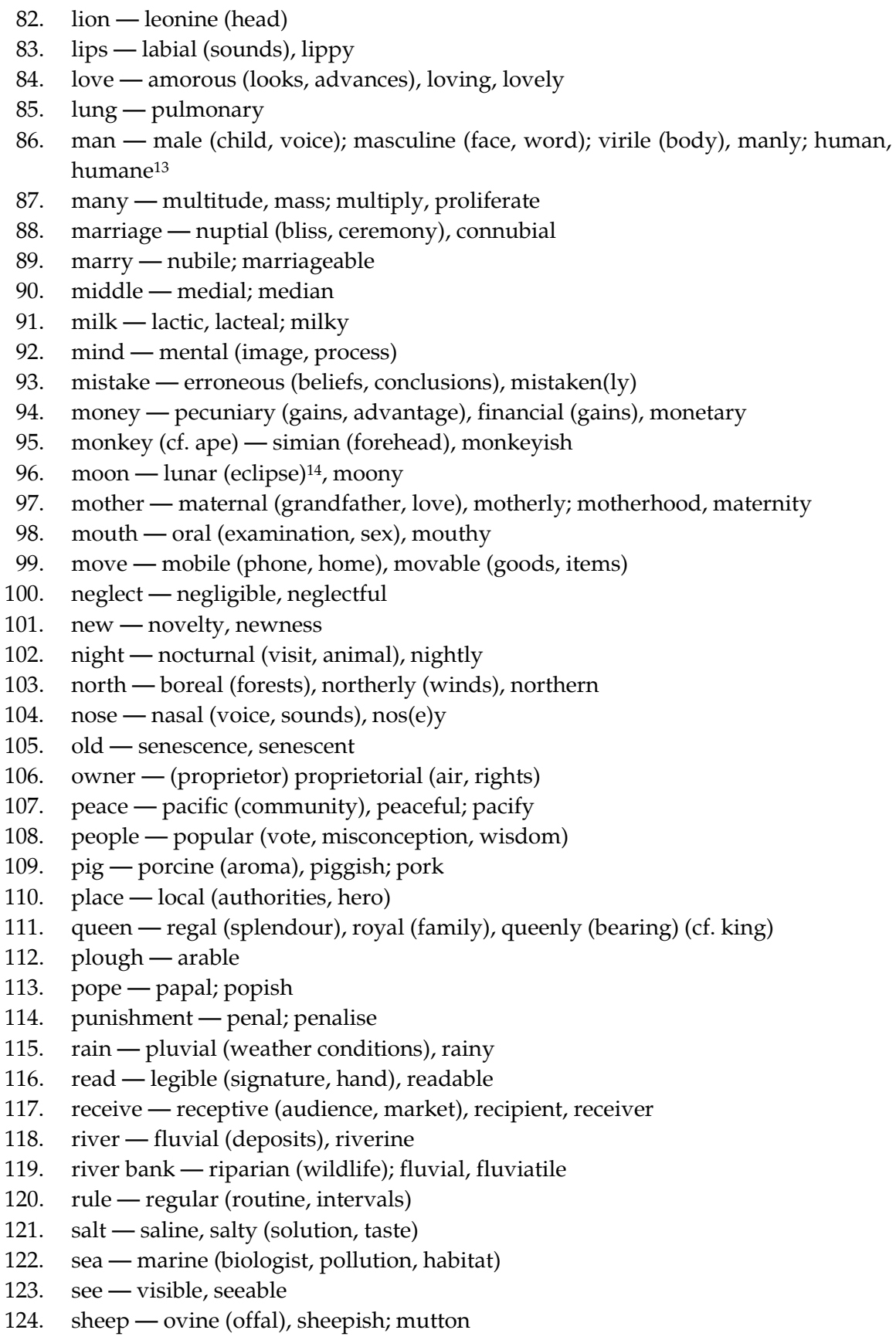




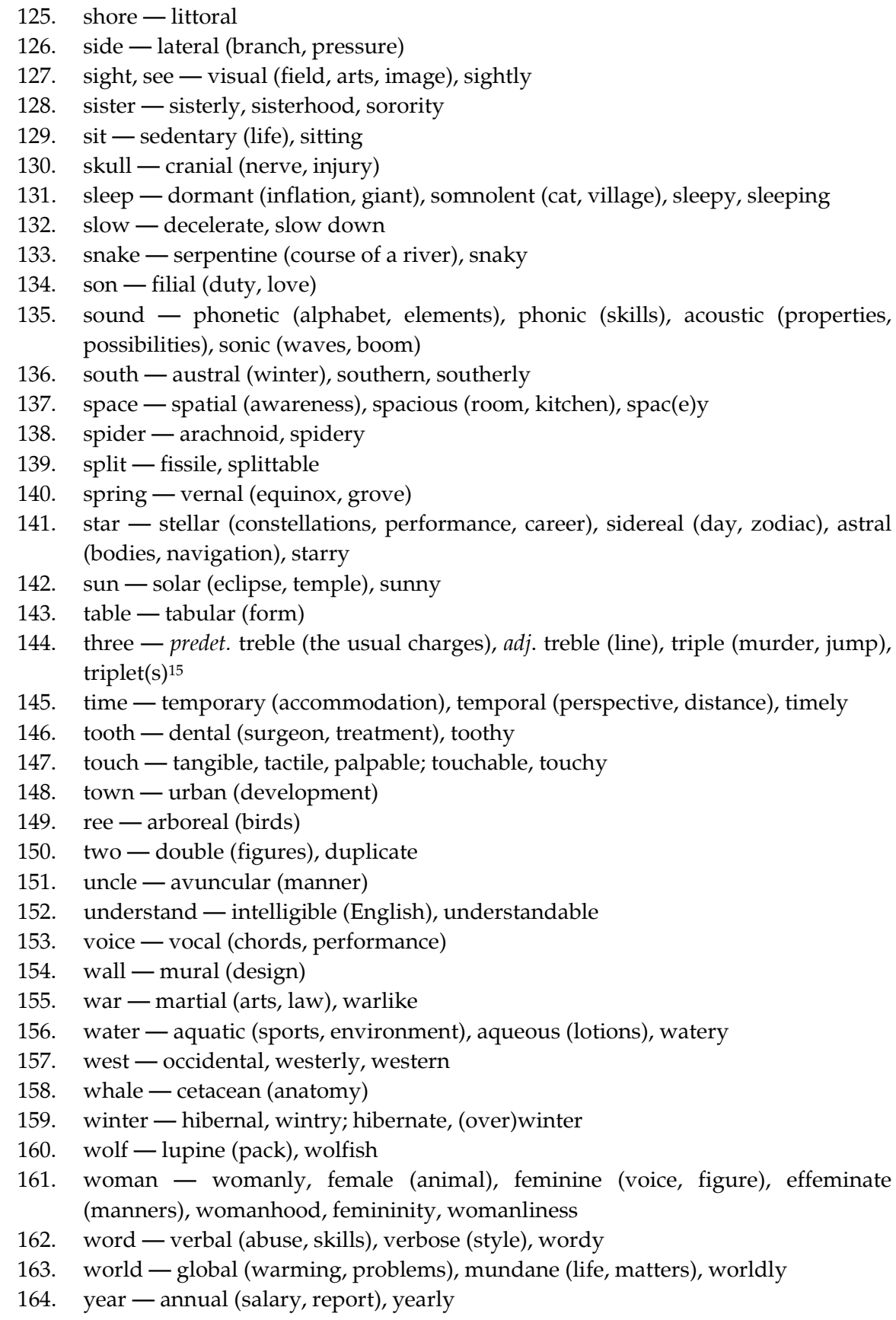


165. young - rejuvenate

166. youth - juvenile (delinquency, offender), youthful

\section{Endnotes}

1. This part of my article is an elaboration of Van der Meer (2000).

2. Cf. the frequent error of mitigate against instead of militate against in English newspapers, caused by the phonetic similarity of two otherwise formally opaque, i.e. morphologically unmotivated, words.

3. "Largely", because the (second) [k] in koninklijk is due to historical conditions, and no longer productive.

4. Strictly speaking, -zicht- is a noun meaning "vision", so that the gloss might instead be "through-sight-ish(-ness)", etc.

5. See Fill 1980: 136 for this example. This quite original study compares English with German word transpaency. Wortdurchsichtigkeit in the title of Alwin Fill's book, to illustrate my point once again, translates literally as "word-through-see-able-ness".

6. Incidentally, the word eclipse itself, when compared with Dutch verduistering (consisting of the prefix ver-, the adjective duister and the nominalising suffix -ing) might also be called opaque and hence "unmotivated". This too is an example of how many loanwords reduce what might be called the "morphological content" of a language.

7. Aptly called "noncognate relationships" by Heuberger (2000).

8. In some cases, e.g. aural, the compilers themselves may not have felt any strong connection between ear and aural, since none of the four learner's dictionaries uses ear in the definition.

9. Also cf. nose where nasal is pointed out.

10. CC uses the extra column for synonyms and antonyms, so that this column occasionally provides the looked for "base".

11. Though strictly speaking this is Latin from Latin, I have included a couple of such cases because these derivations, too, are not so easy for foreign learners.

12. Also cf. hexagenarian, septuagenarian and of course nonagenarian.

13. Here man as a "human being" is meant.

14. There is even a futher complication in selenography, where the combining form seleno- (from Greek) is used, where Dutch, for example, would simply have maanbeschrijving "moon description".

15. Cf. quadruplet (four), quintuplet (five), sextuplet (six), etc.

\section{Bibliography}

\section{A. Dictionaries}

CC: Sinclair, J. (Ed.). 1995². Collins COBUILD English Language Dictionary. London: HarperCollins.

CIDE: Procter, P. (Ed.). 1995. Cambridge International Dictionary of English. Cambridge: Cambridge University Press. 
LDOCE: Summers, D. (Ed.). 1995³. Longman Dictionary of Contemporary English. Harlow: Longman.

OALD: Wehmeyer, S. (Ed.). 20006. Oxford Advanced Learner's Dictionary of Current English. Oxford: Oxford University Press.

\section{B. Other sources}

Cowie, A.P. 1999. English Dictionaries for Foreign Learners. A History. Oxford: Oxford University Press.

Fill, Alwin. 1980. Wortdurchsichtigkeit im Englischen. Eine nicht-generative Studie morphosemantischer Strukturen. Mit einer kontrastiven Untersuchung der Rolle durchsichtiger Wörter im Englischen und Deutschen der Gegenwart. Innsbruck: Universität Innsbruck.

Heuberger, Reinhard. 2000. Monolingual Dictionaries for Foreign Learners of English. A Constructive Evaluation of the State-of-the-Art Reference Works in Book Form and on CD-Rom. Vienna: Wilhelm Braumüller.

Van der Meer, Geart. 2000. Further Ways to Improve the Active Dictionary: Collocations, Nonmorphological Derivations, Grammar. Mogensen, Jens Erik, Viggo Hjørnager Pedersen and Arne Zettersten (Eds.). Symposium on Lexicography IX. Proceedings of the Ninth International Symposium on Lexicography, April 23-25, 1998 at the University of Copenhagen: 125-141. Tübingen: Max Niemeyer. 